\title{
HAZARDS TO BIRDS FROM OPEN METAL PIPES
}

\author{
Charles D. Hathcock ${ }^{1,2}$ and Jeanne M. Fair ${ }^{1}$
}

\begin{abstract}
There are reports of open polyvinyl chloride (PVC) pipes causing bird deaths in the western United States (Brattstrom 1995). Here, we document cases of open bollards and open pipes on gates causing bird deaths in northern New Mexico. At Los Alamos National Laboratory (LANL), a 10,240-ha site, over 100 uncapped $10.16 \mathrm{~cm}$ diameter protective bollard posts were examined, and $27 \%$ of the open bollards contained dead birds. A total of 88 open pipes used as gate posts, with diameters of $8.89 \mathrm{~cm}$ or $10.16 \mathrm{~cm}$, were examined, and $11 \%$ contained dead birds. We conducted a preliminary assessment of open pipes on gates along a highway on federal land north of LANL, and $14 \%$ of the open pipes contained dead birds. This gate configuration, with open pipes anchoring the gate on either side, is very common in the western United States. In all cases, Western Bluebirds (Sialia mexicana) composed the majority of the identifiable birds we discovered. Based on these preliminary findings, the number of bird deaths from this source is potentially very large and should be a concern in bird conservation and management.
\end{abstract}

RESUMEN.-Existen informes de que tuberías de policloruro de vinilo (PVC) sin sellar causan la muerte de aves en el oeste de Estados Unidos (Brattstrom 1995). Aquí documentamos casos de bolardos y tuberías sin cubrir en puertas que causan la muerte de aves al norte de Nuevo México. En el Laboratorio Nacional de Los Álamos (LANL), en un área de 10,240 hectáreas, se examinaron más de 100 postes de bolardos protectores sin cubrir de 10.16 centímetros de diámetro y el $27 \%$ de estos bolardos contenían aves muertas. Además, se examinaron un total de 88 tuberías abiertas utilizadas como postes en puertas de entrada, con diámetros de $8.89 \mathrm{~cm}$ o $10.16 \mathrm{~cm}$, y el $11 \%$ de ellas contenían aves muertas. Se llevó a cabo una evaluación preliminar de las tuberías sin sellar en puertas a lo largo de una autovía, propiedad federal al norte del LANL, y el 14\% de estas tuberías contenían aves muertas. Esta configuración de puertas con tuberías sin sellar anclando la puerta por cualquiera de sus lados es muy común en el oeste de los Estados Unidos. En todos los casos, la mayoría de las aves reconocibles que fueron encontradas eran Azulejos de Garganta Azul (Sialia mexicana). Basándose en estos descubrimientos preliminares, la proporción de muertes de aves por este motivo es potencialmente muy elevada y debería ser de interés para la conservación y el manejo de las aves.

In May 2013, wildlife biologists at the Los Alamos National Laboratory (LANL) were notified of several birds discovered dead at the bottom of a protective bollard. Bollards are short vertical posts used extensively for traffic control and physical security of buildings and facilities. Most bollards are made of metal pipe and are capped or covered in some way. At LANL, protective bollards were installed around regional water monitoring wells. These bollards were made of $10.16 \mathrm{~cm}$ diameter metal pipe and in many instances were not capped. Biologists also observed that many gates at LANL had $10.16 \mathrm{~cm}$ diameter open pipes as anchors. This gate configuration is very common in the western United States, with gates being anchored on both sides by $8.89 \mathrm{~cm}$ or $10.16 \mathrm{~cm}$ diameter pipes.

It was determined that these open bollards and open pipes were causing avian mortalities. Bluebirds, which are secondary cavity-nesting birds, were the most common species found in the pipes. The birds likely investigate the open pipe as a potential nesting site, and once inside they cannot climb the smooth metal or extend their wings to fly out and they perish. Alternatively, birds may attempt to land on the upright open pipes and then fall in.

Birds face many threats, and data from breeding-bird surveys (Robbins et al. 1989) and long-term banding (Osenkowski et al. 2012) show that many species have been in decline for several years. Cavity-nesting birds in particular face threats due to environmental changes that may reduce populations (Adamik and Kral 2008). Threats to birds are well documented, and Erickson et al. (2005) estimated that from 500 million to possibly over one billion birds are killed annually in the United States by anthropogenic causes, including collisions with human-made structures (e.g., vehicles, buildings and windows, power lines,

\footnotetext{
${ }^{1}$ Los Alamos National Laboratory, Environmental Stewardship, Los Alamos, NM 87545.

${ }^{2}$ Present address: Los Alamos National Laboratory, Box 1663, Mailstop J978, Los Alamos, NM 87545. E-mail: hathcock@lanl.gov
} 
communication towers, and wind turbines), electrocutions, oil spills and other contaminants, pesticides, cat predation, and commercial fishing by-catch. Not included in the estimates of Erickson et al. (2005) are mortalities caused by entrapment inside open metal pipes. Wildlife mortalities caused by open polyvinyl chloride (PVC) mine markers on Bureau of Land Management (BLM) land were reported in Brattstrom (1995), and 19\% of the examined posts contained dead birds. Additionally, unpublished evidence is available online from Audubon's Kern River Preserve regarding the threat of open pipes as fence posts (http://kern.audu bon.org/death_pipes.htm). Here, we describe the occurrence and consequences of open pipes on cavity-nesting birds in New Mexico.

\section{METHODS}

The LANL is located in Los Alamos County in north central New Mexico (NM), 100 $\mathrm{km}$ north-northeast of Albuquerque and $\sim 40 \mathrm{~km}$ northwest of Santa Fe. The 10,240-ha site is situated on the Pajarito Plateau on the eastern flanks of the Jemez Mountains. All open bollards and open pipes on gates at LANL were examined. Bright flashlights were used to see the bottom of the open pipe to look for avian mortality. If an open pipe had avian remains at the bottom, then it was recorded as a positive detection. Some of the bollard pipes were removable which allowed for the accounting of multiple mortalities. Recent remains that still contained feathers could be identified to species, but older bones were not identifiable.

To investigate the possibility of region-wide impacts from open pipes on gates, we conducted preliminary searches on Carson National Forest and BLM land 60-100 km northnortheast of Los Alamos County. North of Ojo Caliente, $64 \mathrm{~km}$ of U.S. Route 285 was driven and checked for gates with open pipes. Another $64-\mathrm{km}$ stretch of U.S. Route 285 was driven south of Santa Fe, and gates with open pipes were counted.

\section{RESUlTS}

On LANL property, 100 open bollard pipes were examined, and dead birds were recorded in 27 of the pipes $(\sim 27 \%)$. There were several instances of multiple dead birds per bollard. Of the few removable bollards that contained dead birds, the highest number documented was 5 dead birds in a single bollard. Most of the bollards were not removable, and carcasses or bones at the bottom could not be retrieved, which meant that the number of birds affected could have been higher. Western Bluebirds (Sialia mexicana) accounted for $61 \%$ of the positive detections. Other species documented included Ash-throated Flycatcher (1.1\%; Myiarchus cinerascens), Acorn Woodpecker $(<1 \%$; Melanerpes formicivorus), Spotted Towhee $(<1 \%$; Pipilo maculatus), House Finch $(<1 \%$; Haemorhous mexicanus) and White-breasted Nuthatch $(<1 \%$; Sitta carolinensis). Skulls or other bones that were not identifiable beyond being avian comprised the remaining $\sim 37 \%$.

A total of 88 open pipes on gates were examined at LANL, and dead birds were recorded in 10 of the pipes (11\%), all Western Bluebirds. Additionally, 6 larger-diameter pipes $(19.05 \mathrm{~cm})$ on 3 gates were discovered, and 3 of these larger pipes contained multiple dead birds in each. The dead birds in the larger diameter pipes were 3 Western Scrub-Jays (Aphelocoma californica), 1 Spotted Towhee, 1 Western Bluebird, 1 Green-tailed Towhee (Pipilo chlorurus), and other unidentified skulls and bones. Permanent covers were purchased and installed on all open bollards and pipes used as gate posts at LANL.

Gates with open pipes on Carson National Forest and BLM land were examined on a 64$\mathrm{km}$ stretch of U.S. Route 285 north of Ojo Caliente, and 5 of the 37 (14\%) open pipes contained dead birds, both Western and Mountain Bluebirds (Sialia currucoides). Only gates on public land were examined. In the same stretch of highway, dozens more gates on private land were not checked. Figure 1 shows an example of the gate configuration that is the threat.

\section{Discussion}

We attempted to estimate potential annual losses of birds caused by entrapment in open bollards and open pipes on gates. At LANL alone, it is estimated that $>75$ birds per year perish from this threat. Two rural highways were driven for $64 \mathrm{~km}$ in northern New Mexico, and gates with open pipes were counted. The 2 counts resulted in 1.25 gates per $\mathrm{km}$ and 1.03 gates per $\mathrm{km}$. There are $97,189 \mathrm{~km}$ of rural roadways in New Mexico (USCB 2012), but the number of gates is not published or known. If we assume there are 97,000 gates with open 


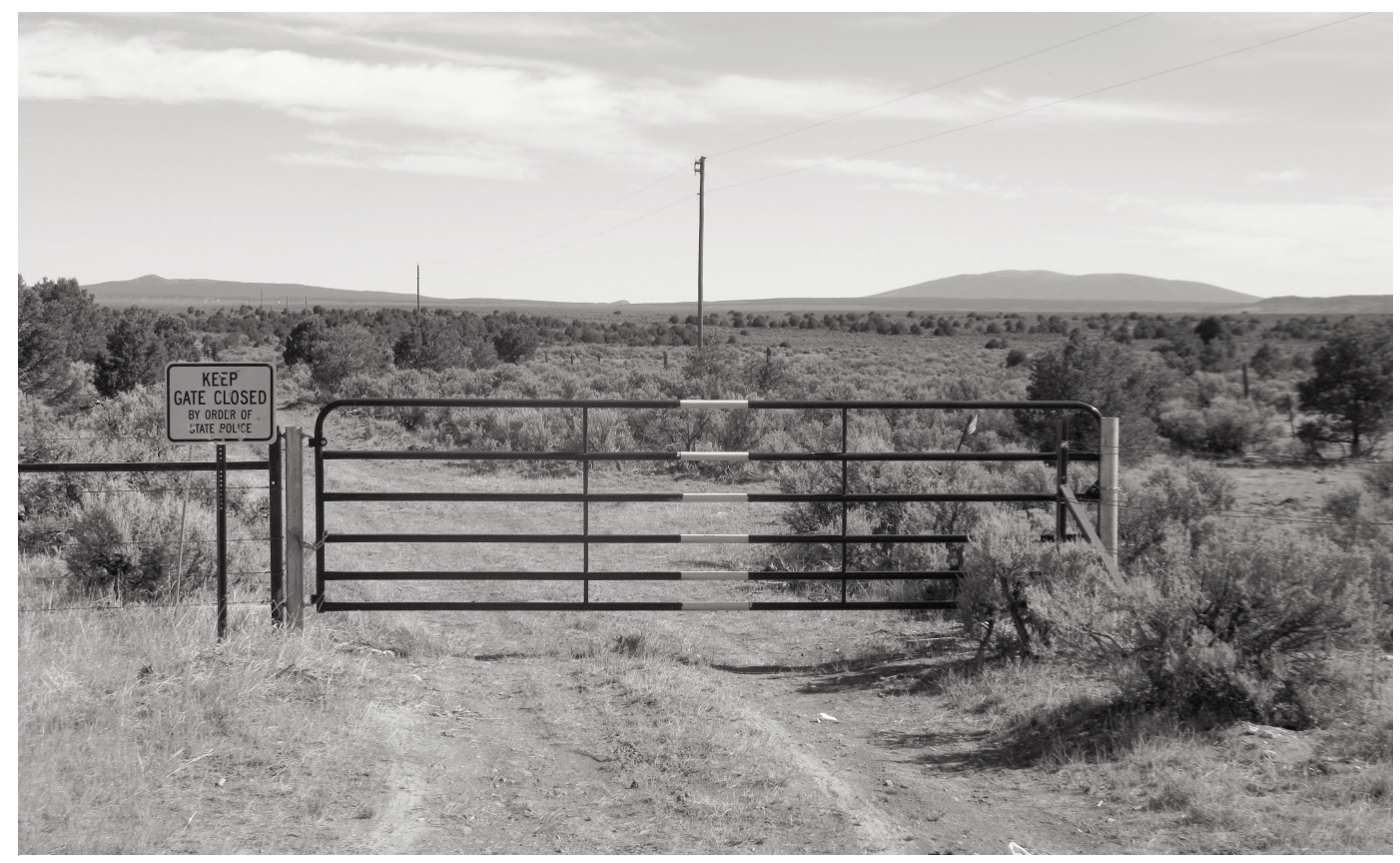

Fig. 1. A typical gate found along rural highways in New Mexico with open $10.16 \mathrm{~cm}$ diameter pipes functioning as anchors on both sides.

pipes in New Mexico and 14\% of them kill birds annually, that is 13,580 potential bird deaths per year. Permanently correcting the problem at a facility such as LANL was simple and costeffective, but correcting this conservation problem across a large region would be challenging.

Based on these preliminary findings and worst-case scenarios, open bollards and pipes pose a potentially large-scale threat to birds, and research on the impacts of this threat, especially to cavity-nesting birds, should be encouraged and considered in management plans.

\section{ACKNOWLEDGMENTS}

We thank M. Alexander, P. Gallagher, S. Terp, J. Payne, D. Keller, H. Mahowald, K. Schoenberg, M. Musgrave, A. Smith, B. Lechel, A. Jacobs, L. Martinez, and P. Maestas. This research was funded by the Environmental Protection Division through Los Alamos National Security, LLC, operator of the Los Alamos National Laboratory under Contract No. DEAC52-06NA25396 for the National Nuclear Security Administration of the U.S. Department of Energy.

\section{Literature Cited}

Adamik, P., AND M. KRaL. 2008. Climate- and resourcedriven long-term changes in dormice populations negatively affect hole-nesting songbirds. Journal of Zoology 275:209-215.

Brattstrom, B.H. 1995. Wildlife mortalities in PVC claim posts. Wildlife Society Bulletin 23:765-766.

ERICKSON, W.P., G.D. JoHNSON, AND D.P. Young. 2005. A summary and comparison of bird mortality from anthropogenic causes with an emphasis on collisions. General Technical Report PSW-GTR-191, Pacific Southwest Research Station, Albany, CA.

Osenkowski, J.E., P.W.C. Paton, and D. Kraus. 2012. Using long-term constant-effort banding data to monitor population trends of migratory birds: a 33year assessment of adjacent coastal stations. Condor 114:470-481.

Robbins, C.S., J.R. Sauer, R.S. Greenberg, and S. Droege. 1989. Population declines in North American birds that migrate to the neotropics. Proceedings of the National Academy of Sciences 86:7658-7662.

[USCB] United States Census Bureau. 2012. Statistical abstract of the United States: 2012. 131st edition. Washington, DC. Available from: http://www.census .gov/compendia/statab/.

Received 4 February 2014 Accepted 30 May 2014 